\title{
SLC43A2 Gene
}

National Cancer Institute

\section{Source}

National Cancer Institute. SLC43A2 Gene. NCI Thesaurus. Code C118998.

This gene is involved in the transport of large neutral amino acids. 